\title{
Production of Hydrocarbon Liquid by Thermal Pyrolysis of Paper Cup Waste
}

\author{
Bijayani Biswal, Sachin Kumar, and R. K. Singh \\ Department of Chemical Engineering, National Institute of Technology, Rourkela, Orissa 769008, India \\ Correspondence should be addressed to Sachin Kumar; sachin044@gmail.com
}

Received 20 December 2012; Revised 10 February 2013; Accepted 16 February 2013

Academic Editor: Yinguang Chen

Copyright (C) 2013 Bijayani Biswal et al. This is an open access article distributed under the Creative Commons Attribution License, which permits unrestricted use, distribution, and reproduction in any medium, provided the original work is properly cited.

\begin{abstract}
The paper cup waste was pyrolysed in a stainless steel semibatch reactor at a temperature range of $325^{\circ} \mathrm{C}$ to $425^{\circ} \mathrm{C}$ and at a heating rate of $20^{\circ} \mathrm{C} \mathrm{min}{ }^{-1}$ with an aim to study the physical and chemical characteristics of the obtained hydrocarbon liquid and to determine its feasibility as a commercial fuel. The maximum liquid yield was $52 \%$ at $400^{\circ} \mathrm{C}$. The functional groups present in the liquid are aldehydes, ketones, carboxylic acids, esters, alkenes, and alkanes. It was found that the pyrolytic liquid contains around 18 types of compounds having carbon chain length in the range of $\mathrm{C}_{6}-\mathrm{C}_{20}$. The obtained liquid can be used as valuable chemicals feedstock.
\end{abstract}

\section{Introduction}

Urbanization is an important determinant of both the quantity and the type of fuel used in developing countries. In general, urbanization leads to higher levels of energy consumption, also accompanied with increases in income levels. Therefore, there is a shift from traditional to commercial fuels. Several other factors that contribute to this trend include decline in access to biomass fuels, inconvenience of transportation and storage of biomass fuels, and improvement unavailability of commercial fuels in urban areas [1]. The disposal of solid biomass and waste is becoming an enormous problem because they are very difficult and costly to manage. Pyrolysis has proved itself to be a new type of solid biomass and waste utilization technique that transforms biomass and waste material of low-energy density into bio-oil of high-energy density and recover higher value chemicals. Paper cups used as coffee or cold drinks cups are accumulating as wastes on the earth surface at a rapid rate. Considering only America, 14.4 million disposable paper cups are used for drinking coffee each year. Placed end-toend, these cups would wrap around Earth 55 times and weigh around 900 million pounds.

Most paper cups are designed for a single use and then disposed or recycled. One paper cup represents $4.1 \mathrm{~g}$ equivalent petrol with a production cost 2.5 times higher than plastic cups. Paper cups are not specifically recycled. They come under regular waste and burnt or put on landfills. Recycling paper cups is difficult because of its composition as a complex of paper and paraffin. Hence, they need about 150 years (same as plastics) to degrade because of their plastic foil [2]. The paper cups for hot drinks are produced from wood pulp (cellulose) and polyethylene plastic film, made out of petrol or paraffins, to improve its water resistivity and resistance to heat. They have a coating of $8-18 \mathrm{~g} / \mathrm{m}^{2}$ on one side. Cups for cold drinks have $6-15 \mathrm{~g} / \mathrm{m}^{2}$ on the top side and $8-18 \mathrm{~g} / \mathrm{m}^{2}$ on the reverse side [3]. A basic hot beverage cup is typically made of $95 \%$ (by wt) of paper and 5\% (by wt) of polyethylene for coating. In cold drink cup, polythene used is $10 \%$ and fiber is $90 \%$. The paper used is produced from valuable "bleached kraft" fibres [3]. Mixed paper wastes (MPW) represent a valuable source of energy. Hence, it is studied to determine the quantity of energy obtained from waste of known amount and composition. For a waste to become an energy system, the heating value of waste is one of the important characteristics that determine the energy obtainable from wastes [4]. Mixed paper wastes comprising a mixture of newspaper, cardboard, kraft, beverage and milk boxes, boxboard, tissue, colored office paper, white office paper, envelopes, treated paper (NCR), and glossy paper were studied for their combined calorific value as shown in Table 1 [4]. 
TABLE 1: Calorific value of different paper waste [4].

\begin{tabular}{lc}
\hline Type of paper & Mean gross calorific value (Btu/lb) \\
\hline Newspaper & 7540 \\
Cardboard & 6907 \\
Kraft & 6897 \\
Beverage and milk boxes & 6855 \\
Boxboard & 6703 \\
Tissue & 6518 \\
Colored office paper & 6348 \\
White office paper & 6234 \\
Envelopes & 6160 \\
Treated paper (NCR) & 5983 \\
Glossy paper & 6370 \\
Mixed & 6477 \\
\hline
\end{tabular}

The expected calorific value of any unknown sample of mixed paper can be calculated by using the calorific values of each individual category of mixed waste paper (MWP) and the weight fraction of each in a MWP sample [4].

As paper cups are low-density polyethylene (LDPE) coated, so the study of pyrolysis of waste paper and LDPE could be of some help. Li et al. studied the influence of pyrolysis temperature and heating rate on yield of pyrolysis products from waste paper and concluded that the maximum biooil yield of $49.13 \%$ was achieved at a temperature around $420^{\circ} \mathrm{C}$ with heating rate of $30^{\circ} \mathrm{C} \mathrm{min}{ }^{-1}$. The results of spectroscopic and chromatographic analysis show that bio-oil contained many different chemical classes, and there are four main different compounds in bio-oil: anhydrosugars, carboxyl compounds, carbonyl compounds, and aromatic compounds [5]. Pyrolysis of uncoated printing and writing paper was carried out by Wu et al. in a TGA reaction system at a constant heating rate of $5 \mathrm{~K} \mathrm{~min}^{-1}$ and in a nitrogen environment. The gaseous products investigated included nonhydrocarbons $\left(\mathrm{H}_{2}, \mathrm{CO}, \mathrm{CO}_{2}\right.$, and $\left.\mathrm{H}_{2} \mathrm{O}\right)$ and hydrocarbons $\left(\mathrm{C}_{1}-\mathrm{C}_{3}, \mathrm{C}_{4}, \mathrm{C}_{5}\right.$, $\mathrm{C}_{6}$, benzene, $\mathrm{C}_{10}-\mathrm{C}_{12}$, levoglucosan, $\mathrm{C}_{13}-\mathrm{C}_{15}$, and $\mathrm{C}_{16}-\mathrm{C}_{18}$ ). The cumulated masses and the instantaneous concentrations of gaseous products were obtained under the experimental conditions. The yields of non-hydrocarbon gases and of hydrocarbons were about 10.46 and $0.49 \%$ at $623 \mathrm{~K}, 33.68$ and $0.89 \%$ at $700 \mathrm{~K}, 64.52$ and $1.05 \%$ at $788 \mathrm{~K}$, and 79.10 and $1.63 \%$ at $938 \mathrm{~K}$, respectively. Since the synthetic gases $\left(\mathrm{CO}, \mathrm{CO}_{2}\right.$, $\mathrm{H}_{2} \mathrm{O}, \mathrm{HCs}$ ) contained a high calorific value, their use as marketable fuels gently supported the importance for resource recycling of the uncoated printing and writing paper [6]. Shah et al. have pyrolysed waste LDPE in a home-assembled batch reactor under atmospheric pressure using a wide range of acidic and basic catalyst like silica, calcium carbide alumina, magnesium oxide, and homogenous mixture of silica and alumina. $\mathrm{CaC}_{2}$ proved advantageous on basis of reaction time while the efficiency of conversion to liquid was more for $\mathrm{SiO}_{2}$ at optimum conditions. Hence, these two can be suitably used for catalytic pyrolysis of polyethylene (optimum weight$1 \mathrm{~g} / 5 \mathrm{~g}$ of LDPE). Oxide containing catalyst could be best suited for selective conversion into polar and aromatic compounds while $\mathrm{CaC}_{2}$ could be adopted for selective conversion into aliphatic products [7]. The liquid product obtained from catalytic pyrolysis was characterized by physical and chemical tests. Physical tests include density, specific gravity, API gravity, viscosity, aniline point, flash point, and gross calorific value. These were determined according to IP and ASTM standard methods for fuel values. The liquid fraction obtained is comparable with the standard results of physical tests for gasoline, kerosene and diesel fuel oil. Chemical tests like bromine water and $\mathrm{KMnO}_{4}$ tests the presence of mixture of olefin, and aromatic compounds can be obtained. Components in the oil mixture were separated by column chromatography and fractional distillation followed by characterization with FTIR spectroscopy [7].

The objective of the present work is to optimize the liquid fuel production from waste paper cups by thermal pyrolysis in a semibatch reactor. This work also reports on the characterization of the liquid fuel using FTIR, GC-MS for composition, and other standard methods for studying different physical properties.

\section{Materials and Methods}

Paper cups waste has been collected from NIT campus area in Rourkela, Orissa (India). The cups were cut into small squareshaped pieces (about $1 \mathrm{~cm}$ side). The proximate analysis of paper cups waste and char obtained after pyrolysis was done by ASTM D3173-75 and ultimate analysis was done using CHNS analyzer (elementar vario EL cube chnso). Calorific value of the raw material and the obtained char was done by ASTM D5868-10a.

Thermogravimetric analysis of the waste paper cup sample was carried out with a shimadzu DTG-60/60H instrument. A known weight of the sample was heated in a silica crucible at a constant heating rate of $25^{\circ} \mathrm{C} / \mathrm{min}$ operating in a stream of nitrogen with a flow rate of $25 \mathrm{~mL} / \mathrm{min}$ from $32^{\circ} \mathrm{C}$ to $700^{\circ} \mathrm{C}$.

The pyrolysis setup consists of a semi batch reactor made of stainless steel tube (length, $145 \mathrm{~mm}$, internal diameter, $37 \mathrm{~mm}$ and outer diameter, $41 \mathrm{~mm}$ ) sealed at one end and an outlet tube at the other end. The reactor is heated externally by an electric furnace, with the temperature being measured by a Cr-Al: K type thermocouple fixed inside the reactor, and temperature is controlled by external PID controller as shown in the previous study [8]. $15 \mathrm{~g}$ of waste paper cup sample was loaded in each pyrolysis reaction. The condensable liquid products/wax were collected through the condenser and weighed. After pyrolysis, the solid residue left out inside the reactor was weighed. Then, the weight of gaseous/volatile product was calculated from the material balance. Reactions were carried out at different temperatures ranging from 325$425^{\circ} \mathrm{C}$ with a temperature difference of $25^{\circ} \mathrm{C}$.

Fourier transform infrared spectroscopy (FTIR) of the pyrolytic oil obtained at optimum condition was taken with a Perkin-Elmer Fourier-transformed infrared spectrophotometer with resolution of $4 \mathrm{~cm}^{-1}$, in the range of $400-$ $4000 \mathrm{~cm}^{-1}$ to know the functional group composition. The components of liquid product were analyzed using GCMS-QP 2010 (shimadzu). The GC conditions, column oven 


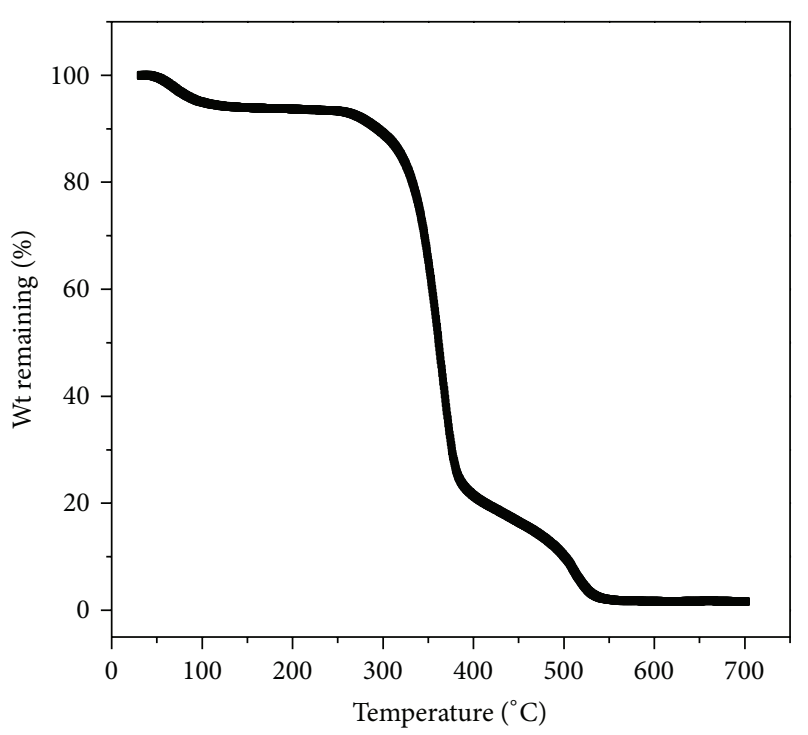

FIgURE 1: TGA plot of paper cup waste.

temperature progress, column used, and MS conditions are given in Table 2. Physical properties such as density, specific gravity, viscosity, Conradson carbon, flash point, fire point, pour point, cloud point, calorific value, sulphur content, and cetane index of the liquid were determined using the standard test methods. The water content in liquid product was determined by the Karl Fischer method and was separated by the gravity separation of the liquid.

\section{Result and Discussion}

3.1. Proximate and Ultimate Analysis of Paper Cup Waste and Obtained Char. The proximate and ultimate analyses of waste paper cup sample are shown in Table 3. The volatile matter is $52 \%$ in the proximate analysis which is drastically reduced to $12 \%$ after pyrolysis. It indicates high conversion of biomass to liquid fuels. As a result of decrease in volatile matter content, fixed carbon of material increased significantly which means there is less liberation of fixed carbon. Ultimate analysis presented in Table 3 showed significant variation in carbon and oxygen content, whereas there were slight variations in hydrogen, nitrogen, and sulphur content.

3.2. TGA and DTG Analysis of Paper Cup Waste. Thermogravimetric analysis (TGA) is a very useful thermal analysis technique to investigate the thermal stability of a material, or to investigate its behavior in different atmospheres (e.g., inert or oxidizing). TGA applied for the study of thermal stability/degradation of paper cup waste in various ranges of temperature. The characteristic parameters of devolatilization are presented in this section. The TGA plot of waste paper cups at a heating rate of $25^{\circ} \mathrm{C} / \mathrm{min}$ under nitrogen atmosphere is shown in Figure 1. The TGA of paper cup waste shows that the active pyrolytic zone was in between the temperature range of $260-410^{\circ} \mathrm{C}$. In this case, the first stage decomposition represents the evaporation of moisture

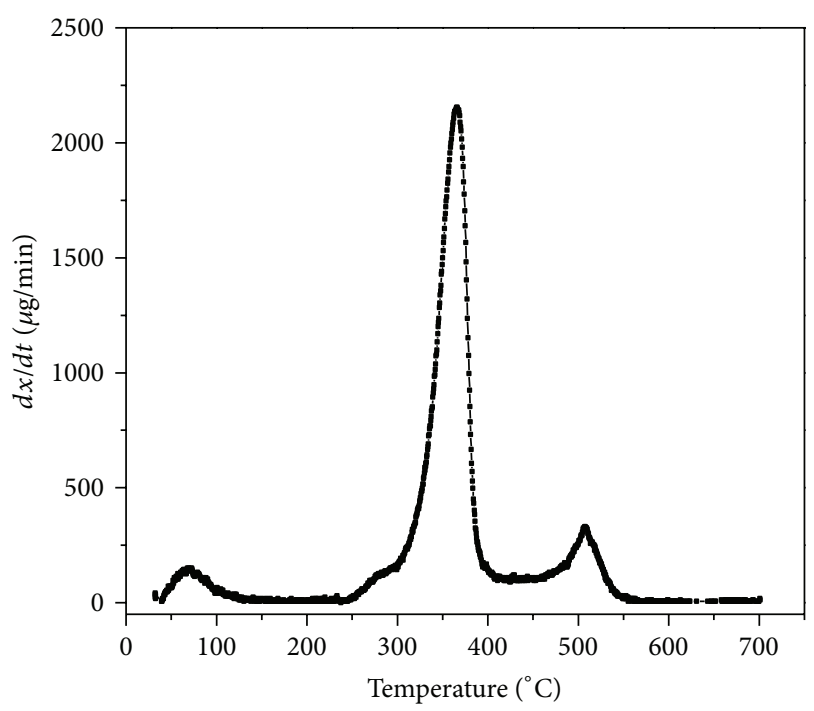

FIGURE 2: DTG plot of paper cup waste.

contents; second decomposition indicates the formation of volatiles mainly $\mathrm{CO}$ and $\mathrm{CO}_{2}$. During the third stage, the pyrolysis residue slowly decomposed, with the weight-loss velocity becoming smaller and smaller, and the residue ratio tends to be constant at the end the decomposition of hydrocarbon. A three-stage weight loss is observed. In the initial or first stage decomposition, $7.39 \%$ weight loss was observed which represents the removal of moisture content. In active pyrolytic zone or second stage decomposition, $70.42 \%$ weight loss was observed, and in the third stage decomposition, $22.19 \%$ weight loss was observed. Due to high decomposition rate per unit time, the rapid decomposition zone or scecond stage of decomposition is treated as active pyrolytic zone. During the second stage, the intermolecular associations and weaker chemical bonds are destroyed [913]. The side aliphatic chains may be broken, and some small gaseous molecules are produced at the lower temperature. During the third stage at higher temperature chemical bonds are broken and the parent molecular skeletons are destroyed. As a result, the larger molecule decomposes to form smaller molecules.

Differential thermogravimetry (DTG) (Figure 2) curve for paper cup waste contains one major peak; this indicates that there is one key degradation step in Figure 2. The dominant peak was at a temperature from $270^{\circ} \mathrm{C}$ to $405^{\circ} \mathrm{C}$ where the maximum decomposition occurred. Similarly, the active pyrolysis zone for glossy paper waste was $274-361^{\circ} \mathrm{C}$ where the maximum weight loss occurred [14]. Similar trend has been observed for the newspaper where the second decomposition of the newspaper occurred between $291^{\circ} \mathrm{C}$ and $429^{\circ} \mathrm{C}$, representing a $63.2 \%$ weight loss [15].

3.3. Effect of Temperature on Product Distribution and Reaction Time. The pyrolysis of paper cup waste yielded three different products, that is, oil, gas, and residue. The distributions of these fractions are different at different temperatures and are shown in the Table 4. 
TABLE 2: GC-MS conditions.

\begin{tabular}{|c|c|c|}
\hline Instrument & $\begin{array}{l}\text { GC-MS-OP } 2010 \\
\text { [SHIMADZU] }\end{array}$ & \\
\hline \multicolumn{3}{|l|}{ GC conditions } \\
\hline $\begin{array}{l}\text { Column oven } \\
\text { temperature }\end{array}$ & $70^{\circ} \mathrm{C}$ & \\
\hline Injection mode & Split & \\
\hline Injection temperature & $200^{\circ} \mathrm{C}$ & \\
\hline Split ratio & 10 & \\
\hline Flow control mode & Linear velocity & \\
\hline Column flow & $1.51 \mathrm{~mL} / \mathrm{min}$ & \\
\hline Carrier gas & Helium $99.9995 \%$ purity & \\
\hline \multicolumn{3}{|l|}{$\begin{array}{l}\text { Column oven temperature } \\
\text { progress }\end{array}$} \\
\hline Rate & Temperature $\left({ }^{\circ} \mathrm{C}\right)$ & $\begin{array}{l}\text { Hold time } \\
\quad(\min )\end{array}$ \\
\hline- & 70 & 2 \\
\hline 10 & 300 & $\begin{array}{l}7.0(32 \mathrm{~min} \\
\text { total })\end{array}$ \\
\hline \multicolumn{3}{|l|}{ Column: DB-5 } \\
\hline Length & $30.0 \mathrm{~m}$ & \\
\hline Diameter & $0.25 \mathrm{~mm}$ & \\
\hline Film thickness & $0.25 \mu \mathrm{m}$ & \\
\hline \multicolumn{3}{|l|}{ MS conditions } \\
\hline Ion source temperature & $200^{\circ} \mathrm{C}$ & \\
\hline Interface temperature & $240^{\circ} \mathrm{C}$ & \\
\hline Start $m / z$ & 40 & \\
\hline End $m / z$ & 1000 & \\
\hline
\end{tabular}

The oil and gas/volatiles constituted major product as compared to the solid residue fractions. The condensable product obtained at low temperature $\left(325^{\circ} \mathrm{C}\right.$ and $\left.350^{\circ} \mathrm{C}\right)$ was low viscous liquids. With increase in temperature, the liquid was viscous, and the maximum liquid product was $52 \%$ at the temperature $400^{\circ} \mathrm{C}$. The recovery of condensable fraction increased with gradual increase of temperature. Similarly, for the waste paper, a maximum of $49.13 \%$ of the liquid product has been obtained at pyrolysis temperature of $420^{\circ} \mathrm{C}$ [5]. The maximum yield of char $43 \%$ was obtained at the temperature $325^{\circ} \mathrm{C}$. With the increasing temperature, the char yield is decreased. This decrease could be due to secondary decomposition of char residue or not decomposed materials [16]. The yield of gas was decreased with increasing pyrolysis temperature up to $400^{\circ} \mathrm{C}$ and then increases. The highest yield of gas $26.87 \%$ was obtained at a pyrolysis temperature of $425^{\circ} \mathrm{C}$. This is due to the secondary decompositions of the char, and secondary cracking of pyrolysis vapors may enrich the contents of the gas product at higher temperature [16-18]. The effect of temperature is shown in Figure 3. The pyrolysis reaction rate increased and reaction time decreased with increase in temperature.
TABle 3: Proximate and ultimate analysis of paper cup waste and obtained char after pyrolysis.

\begin{tabular}{lcc}
\hline & Paper cup & Paper cup char \\
\hline Proximate analysis (wt\%) & & \\
Moisture content & 0 & 0 \\
Volatile matter & 52 & 12 \\
Ash content & 2 & 8 \\
Fixed carbon & 46 & 80 \\
Ultimate analysis (wt\%) & & \\
C & 46.7 & 77.7 \\
$\mathrm{H}$ & 6.7 & 4.9 \\
$\mathrm{~N}$ & 2.12 & 5.33 \\
$\mathrm{~S}$ & 0 & 0 \\
O & 44.4 & 12.07 \\
C/H molar Ratio & 0.57 & 1.32 \\
C/O molar Ratio & 1.4 & 8.63 \\
Empirical formula & $\mathrm{C}_{1.4} \mathrm{H}_{2.41} \mathrm{~N}_{0.05} \mathrm{O}$ & $\mathrm{C}_{0.017} \mathrm{H}_{0.012} \mathrm{~N}_{0.01} \mathrm{O}_{0.0019}$ \\
Gross calorific value & 20.1 & 25.4 \\
(MJ/Kg) & & \\
\hline
\end{tabular}

\section{Characterization of the Liquid Product}

4.1. FTIR of the Oil Sample Obtained at $400^{\circ} \mathrm{C}$. Fourier transform infrared spectroscopy (FTIR) is an important analysis technique which detects various characteristic functional groups present in oil. Figure 4 shows the FTIR spectra of paper cup waste pyrolytic oil. The $\mathrm{O}-\mathrm{H}$ stretching vibrations at frequency $3409 \mathrm{~cm}^{-1}$ indicate the presence of alcohol. The presence of alkanes is detected at $2851 \mathrm{~cm}^{-1}$ with $\mathrm{C}-\mathrm{H}$ stretching vibrations. $\mathrm{C}=\mathrm{O}$ stretching vibrations at $1714 \mathrm{~cm}^{-1}$ show the presence of aldehydes, ketones, carboxylic acids, esters. The presence of alkenes was detected by $\mathrm{C}=\mathrm{C}$ stretching vibrations at $1644 \mathrm{~cm}^{-1}$. The presence of alcohols, ethers, carboxylic acids, and esters is detected by $\mathrm{C}-\mathrm{O}$ stretching vibrations at $1057 \mathrm{~cm}^{-1}$. C-H bending vibrations at $925 \mathrm{~cm}^{-1}$ indicate the presence of alkenes, and the $\mathrm{C}-\mathrm{H}$ bending vibrations at frequency $811 \mathrm{~cm}^{-1}$ indicate the presence of phenyl ring substitution bands. The results were found consistent when compared with the results of GC-MS.

4.2. GC-MS of the Oil Sample. The GC-MS analysis of the pyrolytic oil sample (Figure 5) is summarized in Table 5. It has been observed that the pyrolytic oil contains around 18 compounds. Taking into account the area percentage, the highest peak areas of total ion chromatogram (TIC) of the compounds were 2-furancarboxaldehyde, 2-furaldehyde, oleanitrile, hexadecanoic acid, hexadecanenitrile, methyl cyclopentenolone, and eicosane. The components present in paper cup waste pyrolytic oil are mostly furan derivatives of ketones, phenols, and the aliphatic hydrocarbons (alkanes) with carbon number $\mathrm{C}_{6}-\mathrm{C}_{20}$.

4.3. Physical Properties of Oil Sample. Table 6 shows the results of physical property analysis of oil obtained from 
TABLE 4: Distribution of different fractions at different temperatures in thermal pyrolysis of paper cup waste.

\begin{tabular}{lcccc}
\hline Temperature $\left({ }^{\circ} \mathrm{C}\right)$ & Oil (wt.\%) & Gas/volatile (wt.\%) & Char (wt.\%) & Reaction time (min.) \\
\hline 325 & 30.33 & 26.67 & 43 & 24 \\
350 & 39.23 & 21.27 & 39.5 & 20 \\
375 & 47.13 & 16.87 & 36 & 18 \\
400 & 52.53 & 13.87 & 33.6 & 15 \\
425 & 42.33 & 26.87 & 30.8 & 8 \\
\hline
\end{tabular}

TABLE 5: GC-MS of paper cup waste pyrolytic oil.

\begin{tabular}{|c|c|c|c|}
\hline Compound & IUPAC name & Area\% & Formula \\
\hline 1-Acetoxy-2-propionoxyethane & Dimethyl 2,2-dimethylpropanedioate & 3.62 & $\mathrm{C}_{7} \mathrm{H}_{12} \mathrm{O}_{4}$ \\
\hline 2-Furancarboxaldehyde, 5-methyl- & Benzene-1,3-diol & 10.36 & $\mathrm{C}_{6} \mathrm{H}_{6} \mathrm{O}_{2}$ \\
\hline Phenol & Hydroxybenzene & 2.34 & $\mathrm{C}_{6} \mathrm{H}_{5} \mathrm{OH}$ \\
\hline 1,2-Cyclopentanedione, 3-methyl- & Cyclohexa-3,5-diene-1,2-diol & 5.06 & $\mathrm{C}_{6} \mathrm{H}_{8} \mathrm{O}_{2}$ \\
\hline 2,3-Dihydro-5-hydroxy-6-methyl-4H-pyran-4-one & 2,3-dihydroxy-4-methylcyclopent-2-en- & 3.27 & $\mathrm{C}_{6} \mathrm{H}_{8} \mathrm{O}_{3}$ \\
\hline Oxetane, 2-Propyl & 4-methylpentan-2-one & 2.85 & $\mathrm{C}_{6} \mathrm{H}_{12} \mathrm{O}$ \\
\hline Maltol & Prop-2-enoyl prop-2-enoate & 5.82 & $\mathrm{C}_{6} \mathrm{H}_{6} \mathrm{O}_{3}$ \\
\hline 2,3-Dihydro-3,5-dihydroxy-6-methyl-4H-pyran-4-one & Cyclobutane-1,1-dicarboxylic acid & 1.17 & $\mathrm{C}_{6} \mathrm{H}_{8} \mathrm{O}_{4}$ \\
\hline 1,4:3,6-Dianhydro-.alpha.-d-glucopyranose & Cyclobutane-1,1-dicarboxylic acid & 12.26 & $\mathrm{C}_{6} \mathrm{H}_{8} \mathrm{O}_{4}$ \\
\hline 2-Furancarboaldehyde, 5-(hydroxymethyl)- & Prop-2-enoyl prop-2-enoate & 18.20 & $\mathrm{C}_{6} \mathrm{H}_{6} \mathrm{O}_{3}$ \\
\hline Tetradecane & Tetradecane & 0.72 & $\mathrm{C}_{14} \mathrm{H}_{30}$ \\
\hline Pentadecane & 7-ethyltridecane & 1.51 & $\mathrm{C}_{15} \mathrm{H}_{32}$ \\
\hline 3-Heptadecene, (Z)- & 4,8,12-trimethyltetradec-1-ene & 1.55 & $\mathrm{C}_{17} \mathrm{H}_{34}$ \\
\hline Eicosane & Icosane & 8.54 & $\mathrm{C}_{20} \mathrm{H}_{42}$ \\
\hline Hexadecanenitrile & (E)-N-[(E)-oct-1-enyl]oct-1-en-1-amine & 1.08 & $\mathrm{C}_{16} \mathrm{H}_{31} \mathrm{~N}$ \\
\hline Hexadecanoic acid & 2-(11-methyldodecoxymethyl)oxirane & 3.59 & $\mathrm{C}_{16} \mathrm{H}_{32} \mathrm{O}_{2}$ \\
\hline Oleanitrile & 2-decyl-1,3,3a,4,7,7a-hexahydroisoindole & 3.86 & $\mathrm{C}_{18} \mathrm{H}_{33} \mathrm{~N}$ \\
\hline Octadecanoic acid & 1-Acetoxyhexadecane & 1.84 & $\mathrm{C}_{18} \mathrm{H}_{36} \mathrm{O}_{2}$ \\
\hline
\end{tabular}

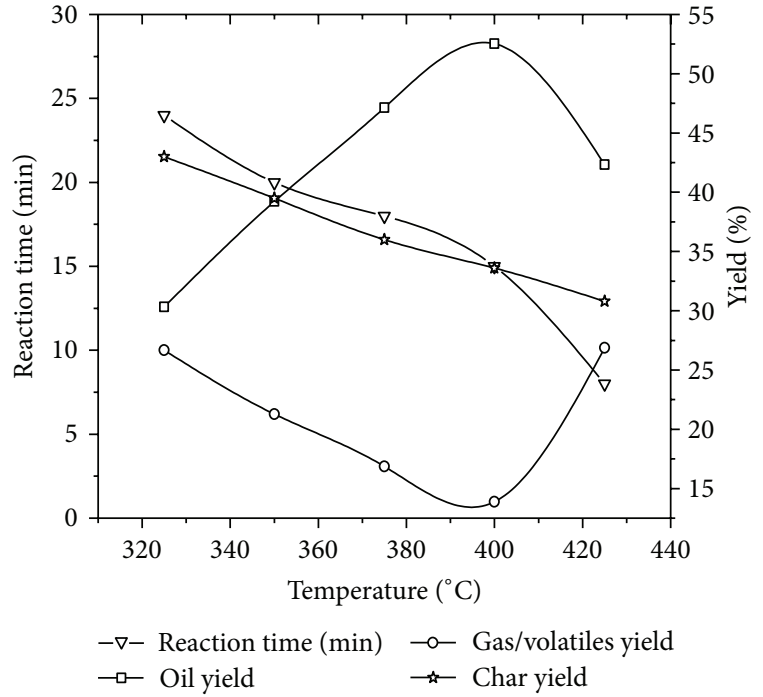

FIGURE 3: Effect of temperature on product yield and reaction time.

pyrolysis of paper cup waste. The appearance of the oil is dark brownish free from visible sediments.

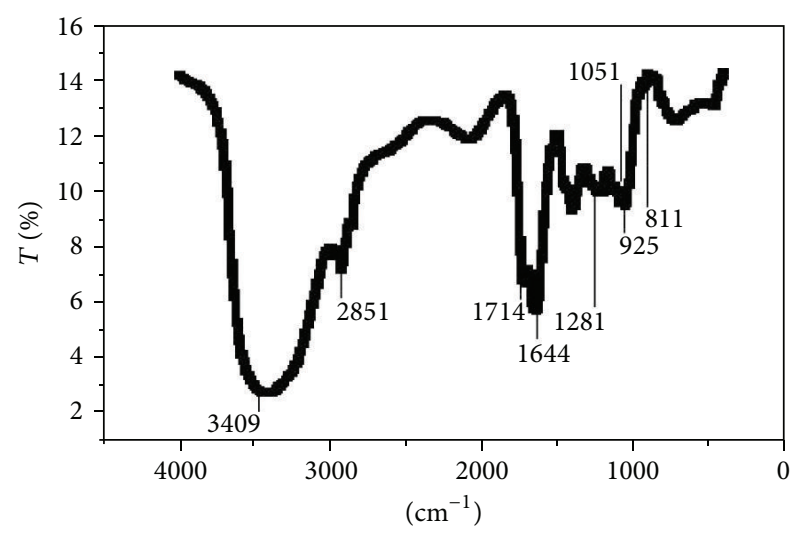

FIGURE 4: FTIR spectrometry of paper cup waste pyrolytic oil.

From comparison with other transportation fuels as shown in Table 7, the density and viscosity of liquid product can be modified by blending it with commercial transportation fuels. The flash point of the liquid product is in a comparable range, and pour point is minus $12^{\circ} \mathrm{C}$ which will not cause any trouble in most of the regions, but in colder regions with subzero climates it may lead to freezing problems. Paper cup waste pyrolytic oil has GCV of $23 \mathrm{MJ} / \mathrm{Kg}$ 
TABLE 6: Physical properties analysis of paper cup waste pyrolytic oil.

\begin{tabular}{lcr}
\hline Properties & Pyrolytic oil & Standard test methods \\
\hline Density at $15^{\circ} \mathrm{C}$ in $\mathrm{kg} / \mathrm{m}^{3}$ & 1.0136 & ASTM D1298-99 \\
Specific gravity at $15^{\circ} \mathrm{C} / 15^{\circ} \mathrm{C}$ & 1.0145 & ASTM D1298-99 \\
Kinematic viscosity at $40^{\circ} \mathrm{C}$ in centistokes & 0.80 & ASTM D445-11 \\
Flash point & $64^{\circ} \mathrm{C}$ & ASTM D6450-05(2010) \\
Pour point & Below $-12^{\circ} \mathrm{C}$ & ASTM D5853-09 \\
Cloud point & $-4^{\circ} \mathrm{C}$ & $\mathrm{Nil}$ \\
Sulphur content & $0.76 \%$ & ASTM D1310-01(2007) \\
Conradson carbon residue & $9.1 \%$ & IS:1448 P:33 \\
Water content & 23 & ASTM D189-06(2010)el \\
Gross calorific value in $\mathrm{MJ} / \mathrm{Kg}$ & & Karl Fischer Method \\
Distillation & & ASTM D5468-02(2007) \\
$\quad$ Initial boiling point & $187^{\circ} \mathrm{C}$ & ASTM D2887-08 \\
Final boiling point & $369^{\circ} \mathrm{C}$ & \\
\hline
\end{tabular}

TABLE 7: Comparison of fuel properties of paper cup waste pyrolytic oil with transportation fuels.

\begin{tabular}{|c|c|c|c|c|c|c|c|c|}
\hline $\begin{array}{l}\text { Fuel } \\
\text { properties }\end{array}$ & $\begin{array}{c}\text { Specific gravity } \\
15^{\circ} \mathrm{C} / 15^{\circ} \mathrm{C}\end{array}$ & $\begin{array}{l}\text { Kinematic viscosity } \\
\text { at } 40^{\circ} \mathrm{C}(\mathrm{cst})\end{array}$ & $\begin{array}{c}\text { Flash point } \\
\left({ }^{\circ} \mathrm{C}\right)\end{array}$ & $\begin{array}{c}\text { Pour point } \\
\left({ }^{\circ} \mathrm{C}\right)\end{array}$ & $\begin{array}{c}\text { GCV } \\
(\mathrm{MJ} / \mathrm{Kg})\end{array}$ & $\begin{array}{l}\text { IBP } \\
\left({ }^{\circ} \mathrm{C}\right)\end{array}$ & $\begin{array}{l}\mathrm{FBP} \\
\left({ }^{\circ} \mathrm{C}\right)\end{array}$ & $\begin{array}{c}\text { Chemical } \\
\text { formula }\end{array}$ \\
\hline $\begin{array}{l}\text { Paper cup } \\
\text { Pyrolytic oil }\end{array}$ & 1.0145 & 0.80 & 64 & $<-12^{\circ} \mathrm{C}$ & 23 & 187 & 369 & $\mathrm{C}_{6}-\mathrm{C}_{18}$ \\
\hline Gasoline [19] & $0.72-0.78$ & - & -43 & -40 & $42-46$ & 27 & 225 & $\mathrm{C}_{4}-\mathrm{C}_{12}$ \\
\hline Diesel [20] & $0.82-0.85$ & $2-5.5$ & $53-80$ & -40 to -1 & $42-45$ & 172 & 350 & $\mathrm{C}_{8}-\mathrm{C}_{25}$ \\
\hline Bio-diesel [20] & 0.88 & $4-6$ & $100-170$ & -3 to 19 & $37-40$ & 315 & 350 & $\mathrm{C}_{12}-\mathrm{C}_{22}$ \\
\hline
\end{tabular}

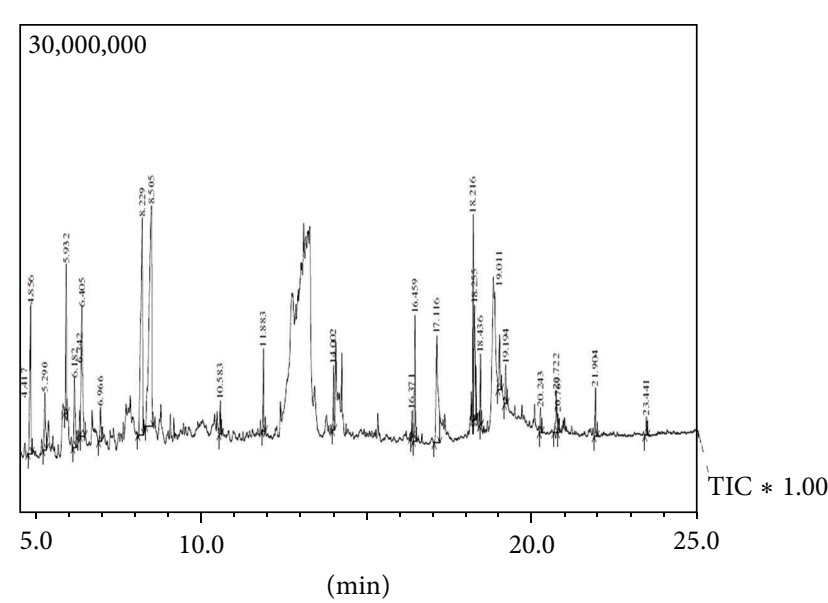

FigURE 5: GC-MS plot of paper cup waste pyrolytic oil.

which is less as compared to that of gasoline and diesel; therefore, this liquid product is a very poor engine fuel. From the distillation report of the oil it is observed that the boiling range of the oil is $187-369^{\circ} \mathrm{C}$, which infers the presence of a mixture of different oil components such as gasoline, kerosene, and diesel in the oil. From this result, it is observed that this hydrocarbon liquid could be possible feedstock for further upgrading or use of lighter compounds as a diesel fuel.

\section{Conclusion}

Thermal pyrolysis of paper cup waste was performed in a semi batch reactor at a temperature range from $325^{\circ} \mathrm{C}$ to $425^{\circ} \mathrm{C}$ and at a heating rate of $20^{\circ} \mathrm{C} / \mathrm{min}$. The maximum liquid yield was $52 \%$ at temperature $400^{\circ} \mathrm{C}$; volatile products are mainly obtained at low temperature. Reaction time decreases with increase in temperature. The functional groups present in the pyrolytic oil are aldehydes, ketones, carboxylic acids, esters, alkenes, and alkanes. It was found that the pyrolytic oil contains around 18 compounds having carbon chain length in the range of $\mathrm{C}_{6}-\mathrm{C}_{18}$. The physical properties of pyrolytic oil obtained were in the range of other pyrolytic oils and poor quality fuels. A simple batch pyrolysis method can convert paper cup waste to liquid hydrocarbons with a significant yield which varies with temperature.

\section{References}

[1] D. Oleg and C. Ralph, "Trends in consumption and production: household energy consumption," DESA Discussion paper no. 6, 1999.

[2] "Comparative Study: identifying mug, plastic cup, biodegradable and compostable cups, and paper cups environmental qualities," http://www.eco-collectoor.fr/.

[3] http://www.environmentalgraffiti.com/waste-and-recycling/ news-newest-alternative-fuel-source-paper-cups.

[4] A. Ucuncu, "Energy recovery from mixed paper wastes," Final Report to Sunshares, Durham, NC, USA. 
[5] L. Li, H. Zhang, and X. Zhuang, "Pyrolysis of waste paper: characterization and composition of pyrolysis oil," Energy Sources, vol. 27, no. 9, pp. 867-873, 2005.

[6] C.-H. Wu, C.-Y. Chang, and C.-H. Tseng, "Pyrolysis products of uncoated printing and writing paper of MSW," Fuel, vol. 81, no. 6, pp. 719-725, 2002.

[7] J. Shah, M. R. Jan, F. Mabood, and F. Jabeen, "Catalytic pyrolysis of LDPE leads to valuable resource recovery and reduction of waste problems," Energy Conversion and Management, vol. 51, no. 12, pp. 2791-2801, 2010.

[8] S. Kumar and R. K. Singh, "Recovery of hydrocarbon liquid from waste high density polyethylene by thermal pyrolysis, Braz," Chemical Engineering Journal, vol. 28, no. 04, pp. 659667, 2011.

[9] D. Jinno, A. K. Gupta, and K. Yoshikawa, "Determination of chemical kinetic parameters of surrogate solid wastes," Journal of Engineering for Gas Turbines and Power, vol. 126, no. 4, pp. 685-692, 2004.

[10] P. W. Chan, A. Atreya, and R. B. Howard, "Determination of pyrolysis temperature for charring materials," Proceedings of the Combustion Institute, vol. 32, pp. 2471-2479, 2009.

[11] P. Raman, W. P. Walawender, L. T. Fan, and J. A. Howell, “Thermogravimetric analysis of biomass, devolatilization studies on feedlot manure," Industrial \& Engineering Chemistry Process Design and Development, vol. 20, pp. 630-636, 1981.

[12] C. Liu, J. Yu, X. Sun, J. Zhang, and J. He, “Thermal degradation studies of cyclic olefin copolymers," Polymer Degradation and Stability, vol. 81, no. 2, pp. 197-205, 2003.

[13] A. Demirbas, "The influence of temperature on the yields of compounds existing in bio-oils obtained from biomass samples via pyrolysis," Fuel Processing Technology, vol. 88, no. 6, pp. 591597, 2007.

[14] J. K. Modh, S. A. Namjoshi, and S. A. Channiwala, "Kinetics and pyrolysis of glossy paper waste," International Journal of Engineering Research and Applications, vol. 2, pp. 1067-1074, 2012.

[15] M. N. A. Bhuiyan, M. Ota, K. Murakami, and H. Yoshida, "Pyrolysis kinetics of newspaper and its gasification," Energy Sources A, vol. 32, no. 2, pp. 108-118, 2010.

[16] P. A. Horne and P. T. Williams, "Influence of temperature on the products from the flash pyrolysis of biomass," Fuel, vol. 75, no. 9, pp. 1051-1059, 1996.

[17] L. Fagbemi, L. Khezami, and R. Capart, "Pyrolysis products from different biomasses: application to the thermal cracking of tar," Applied Energy, vol. 69, no. 4, pp. 293-306, 2001.

[18] S. Galvagno, S. Casu, T. Casabianca, A. Calabrese, and G. Cornacchia, "Pyrolysis process for the treatment of scrap tyres: preliminary experimental results," Waste Management, vol. 22, no. 8, pp. 917-923, 2002.

[19] "Petroleum Product Surveys, Motor Gasoline, Summer, Winter 1986/1987," National Institute for Petroleum and Energy Research, 1986.

[20] J. Tuttle and T. V. Kuegelgen, Biodiesel Handling and Use Guidelines, National Renewable Energy Laboratory, 3rd edition, 2004. 

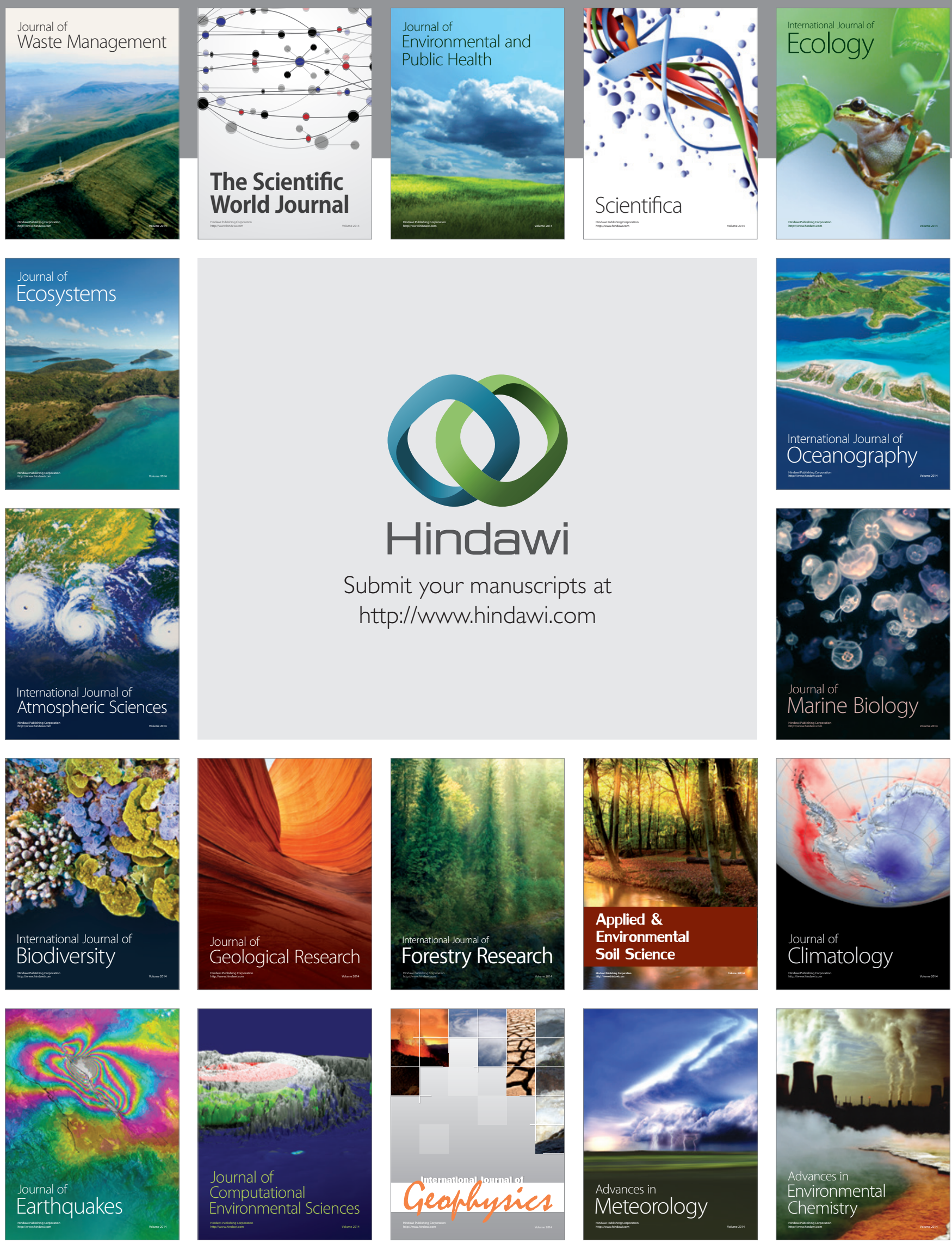